\title{
ANALISIS KOMPARASI KINERJA KEUANGAN PERUSAHAAN MANUFAKTUR YANG BERSERTIFIKAT DAN TIDAK BERSERTIFIKAT ISO 9001:2008
}

\author{
Adi Irawan Setiyantor), Hevi Risdiana ${ }^{2)}$ \\ 1) Jurusan Manajemen Bisini, Politeknik Negeri Batam, Batam 29461, email: adiirawan@ polibatam.ac.id \\ 2) Jurusan Manajemen Bisinis, Politeknik Negeri Batam, Batam 29461, email: \\ hevid yana93@gmail.com
}

\begin{abstract}
Abstrak - Tujuan penelitian ini adalah untuk mengetahui perbedaan kinerja keuangan perusahaan yang memiliki sertifikat ISO 9001:2008 dengan perusahaan yang tidak memiliki sertifikat ISO 9001:2008. Pada penelitian ini kinerja perusahaan diukur dengan Net Asset, Net Profit Margin (NPM), Revenue dan Return On Assets (ROA). Penelitian ini menggunakan data laporan keuangan dari 123 perusahaan manufaktur yang terdaftar di Bursa Efek Indonesia dalam periode 2012-2014. Hasil menunjukkan bahwa perusahaan yang bersertifikasi ISO 9001:2008 dan yang tidak bersertifikasi tidak ada perbedaan yang signifikan terhadap Net Assets, Net Profit Margin dan Revenue, tetapi menunjukkan bahwa perusahaan sertifikasi ISO 9001 memiliki Return On Assets yang berbeda dengan perusahaan yang tidak bersertifikasi ISO 9001.
\end{abstract}

Kata kunci: ISO 9001, Net Asset, Net Profit Margin (NPM), Revenue, Return On Assets (ROA)

\begin{abstract}
The purpose of this study is to determine the differences in financial performance of companies that have ISO 9001: 2008 certificate with companies that do not have ISO 9001: 2008 certificate. In this study the company's performance is measured by Net Asset, Net Profit Margin (NPM), Revenue and Return On Assets (ROA). This study uses financial report data from 123 manufacturing companies listed on the Indonesia Stock Exchange within the period 2012-2014. The results show that ISO 9001: 2008 and non-certified companies have no significant difference to Net Assets, Net Profit Margin and Revenue, but show that ISO 9001 certified companies have different Return On Assets with companies that are not ISO 9001 certified.
\end{abstract}

Key Words: ISO 9001,Net Asset, Net Profit Margin (NPM), Revenue, Return On Assets (ROA) 


\section{PENDAHULUAN \\ 1.1 Latar Belakang}

Perkembangan sistem bisnis di dunia saat ini terjadi peningkatan tekanan terhadap kedua perusahaan. Konsumen dan pesaing terus berinovasi dengan produk baru dan melakukan pembaruan kualitas barang dan jasa mereka. Akibatnya di dalam perusahaan besar baik dinegara maju maupun di negara berkembang telah mendapatkan beberapa bentuk sertifikasi Internasional Organization for Standardization (ISO). ISO bukanlah badan sertifikiasi melainkan penyedia standar untuk menilai proses dan sistem yang ada di dalam perusahaan. Standar yang dimaksud adalah untuk peningkatan efisiensi dan peningkatan kerja. Dibutuhkan beberapa variabel tertentu untuk menentukan apakah standar membawa dampak yang baik dalam organisasi. Penetapan variabel pengukuran kinerja organisasi berguna untuk mengetahui hal-hal apa saja yang berkontribusi dalam keberhasilan organisasi (Ochieng et al., 2015).

Sistem manajemen mutu yang baik dalam perusahaan tentunya akan sangat bermanfaat bagi pihak internal serta pihak eksternal perusahaan. Adanya standar mutu yang baik, perusahaan dipandang memiliki kualitas serta kinerja yang terstruktur dan telah mampu memasok produk sesuai standar. Peningkatan kualitas produk mempunyai tujuan untuk meminimalisasi jumlah produk cacat atau defect. Hal ini akan berdampak terhadap proses pemasaran barang karena pada dasarnya organisasi yang sukses adalah organisasi yang dapat mengubah diri, bergerak cepat dan mampu mengembangkan produk-produk baru secara cepat dan terpasarkan secara cepat pula(Robbins\&Judge, 2008).

Badan usaha dikatakan memiliki kualitas yang baik dan telah menjalankan kaidah-kaidah manajemen secara baik, salah satu cara untuk menilainya yaitu dengan melihat sisi kinerja keuangan. Kinerja keuangan yaitu analisis yang dilakukan untuk melihat apakah suatu perusahaan telah melaksanakan aturan-aturan pelaksanaan keuangan dengan baik dan benar.

Tujuan penelitian ini untuk mengetahui secara empiris perbedaan kinerja keuangan perusahaan bersertifikat ISO 9001:2008 dengan perusahaan tidak sertifikat ISO 9001:2008 pada perusahaan manufaktur yang terdaftar di Bursa Efek Indonesia (BEI).

Penelitian ini, yaitu data yang diperoleh merupakan data perusahaan yang terdaftar di Bursa Efek Indonesia menggunakan perusahaan manufaktur yang menerapkan ISO 9001:2008 dan non-ISO 9001:2008 pada periode 2012 hingga 2014 dan akan dibatasi pada kinerja keuangan yaitu net asset, revenue, net profit, return on assets (ROA).

\section{KAJIAN TEORI}

\subsection{Sistem Manajemen Mutu}

Sistem Manajemen Mutu menurut Gasperz \& Vincent (2002) adalah sekumpulan prosedur yang terdokumentasi dan praktik yang standar untuk manajemen sistem guna menjamin kesesuaian dari suatu proses dan produk (barang/jasa) terhadap kebutuhan atau persayaratan itu ditentukan atau dispesifikan oleh pelanggan atau organisasi. Sistem Manajemen Mutu mendefenisikan bagaimana organisasi menerapkan praktek-praktek manajemen mutu secara konsisten untuk memenuhi kebutuhan pelanggan dan pasar.

\subsection{ISO 9001:2008}

Menurut Cendrawati \& Haryanto (2011) menjelaskan bahwa ISO telah melakukan berapa kali revisi, revisi awal pada tahun 1987 yaitu ISO 9000:1987 berisi tentang model penjaminan mutu untuk proses desain, pengembangan, produk, instalasi dan jasa. Dilakukan pada tahun 1994, sehingga dirumuskanlah ISO 9000:1994 yang memuat tentang standar ISO 9000, 9001, 9002, 9003 dan 9004. Pada tahun 2000 dilakukan revisi terhadap standar ISO untuk menyederhanakan versi sebelumnya yakni versi 1994, Standar versi tahun 2000 mengadopsi pendekatan yang berbasis proses serta delapan prinsip managemen mutu. Revisi terakhir dilakukan pada tahun 2008 sehingga muncul ISO 9001: 2008 sampai saat ini.

Standar ISO 9001:2008berisi tentang beberapa persayaratan sistem managemen mutu yang wajib dipenuhi oleh setiap organisasi yang memiliki sertifikat ISO 9001:2008, yang berguna untuk menyediakan produk sesuai standar sehingga tercapai kepuasan pelanggan dan mematuhi peraturan yang telah diterapkan. Sertifikasi ISO 9001:2008 yang dilakukan secara independen bertujuan untuk memenuhi persayaratan pelanggan dan regulasi pemerintah. Standar ini memiliki beberapa petunjuk untuk kinerja pada jangka panjang, serta memunculkan beberapa manafaat yang dicapai terkait dengan kinerja organisasi (Cendrawati \& Haryanto, 2011).

\subsubsection{Managemen Kualitas}

Menurut Summers (2009) Managemen kualitas adalah suatu alat yang diperlukan karyawan dalam organisasi untuk melakukan identifikasi, desain, 
pengembangan, produksi, pengiriman dan memenuhi produk atau jasa sesuai dengan keinginan pelanggan.

\subsubsection{Kinerja Keuangan}

Suatu badan usaha dikatakan memiliki kualitas yang baik dan telah menjalankan kaidah-kaidah manajemen secara baik, salah satu cara untuk menilainya yaitu dengan melihat sisi kinerja keuangan. Kinerja keuangan yaitu analisis yang dilakukan untuk melihat apakah suatu perusahaan telah melaksanakan aturan-aturan pelaksanaan keuangan dengan baik dan benar. Sumber penilaian tercemin di dalam laporan keuangan perusahaan. Perusahaan dapat memprediksi bagaimana kondisi perusahaan dimasa yang akan datang menggunakan data-data masa lalu. Data keuangan tersebut sebenarnya telah menggambarkan atau setidaknya telah mampu memberikan suatu rekomendasi mengenai kinerja suatu perusahaan atau organisasi. Seorang pemimpin memiliki pengaruh besar dalam mendorong peningkatan kinerja para karyawan yang berdampak pada penciptaan kualitas kerja yang diharapkan. Konsumen dan mitra bisnis akan menyukai hasil produk yang berdampak pada peningkatan keuntungan perusahaan, yang berarti kinerja keuangan yang dihasilkan telah tercapai sesuai dengan harapan (Fahmi, 2011).

\subsection{Kajian Literatur}

Pengaruh sertifikat ISO 9001 terhadap kinerja keuangan telah dibuktikan secara emperis oleh beberapa ahli seperti penelitian yang dilakukan oleh Psomas \& Dimitrios (2014) yang meneliti tentang perbandingan perusahaan yang menggunakan ISO 9001 dan perusahan yang tidak menggunakan ISO 9001 terhadap kinerja perusahaan tersebut terkait dengan kualitas produk, kepuasan pelanggan, oprasional, pasar dan kinerja keuangan. Dari hasil tersebut menunjukkan bahwa perusahaan yang menerapkan ISO 9001 secara signifikan lebih unggul dibandingkan perusahaan yang tidak menerapkan ISO 9001.

Penelitian yang dilakukan oleh Ochieng et al., (2015) yang menguji pengaruh implementasi ISO 9001 terhadap kinerja organisasi yang diukur menggunakan net profit, revenue dan net assets dengan peroide tahun 2010-2013 pada perusahaan yang terdaftar di Nairobi Securities Exchange (NSE). Hasil penelitian oleh Ochieng et al., (2015) menunjukkan bahwa sertifikasi ISO 9001 tidak signifikan terhadapnet profit, turnover dan net assets. Hasil selanjutnya menunjukkan bahwa sertifikasi ISO 9001 berpengaruh positif terhadap ROA.

Hasil penelitian oleh Chatzoglou et al.,(2015) membuktikan bahwa sertifikasi ISO 9000 sangat berkaitan dengan kinerja keuangan. Hasil tersebut menenjukkan bahwa ISO memberikan manfaat bagi perusahaan dan para pemangku kepentingan. Hasil berbeda ditunjukkan oleh Cendrawati \& Haryanto (2011) yang meneliti pengaruh sertifikasi ISO 9000 terhadap rasio return on investment (ROI). Hasil menunjukkan bahwa sertifikasi ISO 9000 tidak berpengaruh positif terhadap kinerja perusahaan yang diukur dengan ROI.

\subsection{Hipotesis}

Pendekatan proses standar ISO terbaru yakni versi ISO 9001:2008, membuat perusahaan berorientasi terhadap suatu proses, kualitas hasil dan kinerja oprasional yang lebih meningkat. Selanjutnya dari pihak eksternal, perusahaan yang menggunakan ISO 9001:2008 dapat meningkatkan kepuasan pelanggan dan pangsa pasar yang lebih besar. Oleh karna itu ukuran kinerja keuangan perusahaan lebih tinggi terhadap perusahaan yang menerapkan QMS dibandingkan perusahan yang tidak menerapkan QMS. Hasil penelitian yang dilakukan oleh Chatzoglou et al., (2015) membuktikan bahwa sertifikasi ISO 9000 sangat berkaitan dengan kinerja keuangan. Hasil tersebut menenjukkan bahwa ISO memberikan manfaat bagi perusahaan dan para pemangku kepentingan.

Analisisi statistik menunjukkan analisis statistik menunjukkan bahwa ISO 9000 secara langsung terkait dengan perbaikan signifikan dalam kualitas kesadaran, pelaksanaan operasi, pasar, kepuasan pelanggan dan pendapatan penjualan.Berdasarkan uraian tersebut hipotesis yang diajukan sebagai berikut:

H1: Terdapat perbedaan net profit antara perusahaan manufaktur yang bersertifikat ISO 9001:2008 dan perusahaan yang tidak bersertifikat ISO 9001:2008

H2: Terdapat perbedaan revenue antara perusahaan manufaktur yang bersertifikat ISO 9001:2008 dan perusahaan yang tidak bersertifikat ISO 9001:2008.

H3: Terdapat perbedaan net assetsantara perusahaan manufaktur yang bersertifikat ISO 9001:2008 dan perusahaan yang tidak bersertifikat ISO 9001:2008.

H4: Terdapat perbedaan return on assets (ROA) antara perusahaan manufaktur yang bersertifikat ISO 9001:2008 dan perusahaan yang tidak bersertifikat ISO 9001:2008.

\section{METODE PENELITIAN}

Dalam penelitian ini, peneliti menggunakan metode penelitian dengan pendekatan kuantitatif. Penulis menggunakan pendekatan kuantitatif sebagai 
metode penelitian karena sumber data yang diperoleh berasal dari data sekunder yaitu berupa annual report atau laporan keuangan tahunan perusahaan yang terdaftar di Bursa Efek Indonesia (basis data). Pada penelitian ini variable independen yang akan diteliti adalah sertifikasi ISO 9001 pada perusahaan manufaktur dan jasa di Bursa Efek Indonesia. Dengan menggunakan variable dummy, perusahaan yang telah menggunakan ISO 9001 diberi notasi 1 sedangkan perusahaan yang belum menggunakan ISO 9001 diberi notasi 0. Variable dependen pada penelitian ini adalah kinerja perusahaan peneliti menggunakan rasio net profit margin, revenue, net asset dan Return On Asset (ROA). Ketentuan dan kriteria penelitian yakni menggunakan perusahaan sektor manufaktur yang telah terdaftar di BEI. Telah memperoleh sertifikat ISO 9001 pada periode 2012 hingga 2014 (3 tahun) dan yang tidak memiliki sertifikat ISO 9001 Tersedia laporan keuangan tahunan periode 2012 hingga 2014 serta yang memiliki nilai buku positif dalam mata uang rupiah. Teknik pengolahan data pada penelitian ini menggunakan SPSS 22.

\section{HASIL DAN PEMBAHASAN}

\subsection{Karakateristik Data}

Populasi dari penelitian ini adalah perusahaan yang terdaftar di IDX dari tahun 2012 hingga tahun 2014.Sampel dari penelitian ini diseleksi berdasarkan ketersediaan data, jumlah populasi perusahaan manufaktur yang terdaftar di bursa efek adalah 144, namun terdapat 21 perusahaan yang tidak dapat dimaksukkan kedalam penelitian, sehingga total sampel dalam penelitian ini berjumlah 123 perusahaan.

Tabel 4.1 Hasil Seleksi Sampel di Indonesia (BEI)

\begin{tabular}{|l|l|}
\hline $\begin{array}{l}\text { Kriteria Seleksi Sampel Penelitian } \\
\text { Perusahaan di Indonesia }\end{array}$ & Jumlah \\
\hline $\begin{array}{l}\text { Perusahaan yang terdaftar di BEI pada } \\
\text { saat ini }\end{array}$ & 144 \\
\hline $\begin{array}{l}\text { Ketidaktersediaan laporan tahunan } \\
\text { selama tahun penelitian }\end{array}$ & $(17)$ \\
\hline $\begin{array}{l}\text { Laporan tidak menggunakan mata uang } \\
\text { rupiah }\end{array}$ & $(4)$ \\
\hline Perusahaan ISO 9001 & $\mathbf{7 6}$ \\
\hline Perusahaan Non-ISO & $\mathbf{4 7}$ \\
\hline Total Perusahaan & $\mathbf{1 2 3}$ \\
\hline
\end{tabular}

Sumber:www.idx.co.id
4.2 Hasil

\subsubsection{Uji Normalitas}

Uji distribusi normal adalah uji untuk mengukur apakah data memiliki distribusi normal. Pengujian dilakukan untuk melihat apakah nilai residual terdistribusi normal atau tidak. Model regresi yang baik memiliki nilai residual yang terdistribusi. Uji yang di pakai adalah KOLMOGOROVSMIRNOV, pengambilan keputusan dikatakan berdistribusi normal jika nilai signifikansi > 0,05 dan jika nilai signifikansi $<0,05$ maka data tidak berdistribusi normal.

\section{Tabel 4.2 Hasil Uji Kolmogorov Smirnov}

\begin{tabular}{|l|l|l|}
\hline Variabel & $\begin{array}{l}\text { Asymp. Sig. (2- } \\
\text { tailed) }\end{array}$ & $\begin{array}{l}\text { Normal jika } \\
>0,05\end{array}$ \\
\hline $\begin{array}{l}\text { Net } \\
\text { Asset }\end{array}$ & 0,919 & Normal \\
\hline Revenue & 0,673 & Normal \\
\hline NPM & 0,746 & Normal \\
\hline ROA & 0,000 & Tidak Normal \\
\hline \multicolumn{2}{|c|}{ Sumber: hasil olahan SPSS (2017) }
\end{tabular}

Pada table diatas dapat dilihat bahwa tingkat signifikansi merupakan 0,000 untuk ROA maka dinyatakan tidak normal, Net Asset 0,919, Revenue 0,673 dan NPM 0,746 data dinyatakan beretribusi normal atau lebih besar dari 0,05 .

\subsection{Pengujian Hipotesis}

Untuk melakukan uji beda pada penelitian ini menggunakan uji non parametik (mann-whitney $u$ test). Mann-Whitney U-test yang digunakan untuk membuat perbandingan antara perusahaan bersertifikat ISO 9001 dan non-ISO 9001 untuk membandingkan jajaran perusahan yang sama (Sulaiman,2003).

Tabel 4.5 Hasil Uji Mann Whitney U-Test

\begin{tabular}{|c|c|c|c|c|}
\hline Pengukuran & Kelompk & Jumlah & $\begin{array}{l}\text { Mean } \\
\text { Rank }\end{array}$ & $\begin{array}{l}\text { Asymp. } \\
\text { Sig } \\
\text { tailed) }\end{array}$ \\
\hline \multirow[t]{3}{*}{ Net Asset } & ISO & 76 & 63.14 & 0.653 \\
\hline & Non-ISO & 47 & 60.16 & \\
\hline & Total & 123 & & \\
\hline \multirow[t]{3}{*}{ Revenue } & ISO & 76 & 63.34 & 0.597 \\
\hline & Non-ISO & 47 & 59.84 & \\
\hline & Total & 123 & & \\
\hline \multirow[t]{3}{*}{ NPM } & ISO & 76 & 63.22 & 0.628 \\
\hline & Non-ISO & 47 & 60.02 & \\
\hline & Total & 123 & & \\
\hline \multirow[t]{3}{*}{ ROA } & ISO & 76 & 72.95 & 0.000 \\
\hline & Non-ISO & 47 & 44.29 & \\
\hline & Total & 123 & & \\
\hline
\end{tabular}

Pada Tabel diatas menunjukkan Mean Rank 
kelompok ISO rata-rata peringkatnya 63,14 lebih tinggi daripada rata-rata peringkat ROA pada kelompok Non-ISO yaitu 60,16. Sedangkan pada Revenue kelompok ISO pada peringkat 63,34 lebih tinggi dibanding kelompok Non-ISO 59,84. Untuk NPM rata-rata kelompok Non-ISO lebih rendah dibanding kelompok ISO, ISO dengan rata-rata 63,22 sedangkan pada Non-ISO 60,02. Kelompok ISO pada ROA juga memiliki rata-rata peringkat yang lebih tinggi dibandingkan kelompok Non-ISO, kelompok ISO dengan rata-rata 72,95 dan Non-ISO 44,29.

Berdasarkan table 4.5 dapat dilihat bahwa seluruh variabel pengukuran signifikan yaitu lebih kecil dari 0,05. Hal ini menyatakan bahwa terdapat perbedaan kinerja pada perusahaan yang memiliki ISO 9001 dengan non-ISO 9001, nilai signifikansi Net Asset $=0.653>0.05$, Revenue $=0,597>0,05$, $\mathrm{NPM}=0,628>0,05, \mathrm{ROA}=0,000<0,05$. Maka hipotesis 1,2 dan 3 dari penelitian ini tidak diterima, yang mana hipotesisnya adalah

H1: Terdapat perbedaan Net Profit Margin antara perusahaan manufaktur yang besertifikat ISO 9001:2008 dan perusahaan yang tidak besertifikat ISO 9001:2008.

H2: Terdapat perbedaan Revenueantara perusahaan manufaktur yang besertifikat ISO 9001:2008 dan perusahaan yang tidak besertifikat ISO 9001:2008.

H3: Terdapat perbedaan Net Asset antara perusahaan manufaktur yang besertifikat ISO 9001:2008 dan perusahaan yang tidak besertifikat ISO 9001:2008.

Dan hipotesis ke-4 diterima, hipotesisnya adalah

H4: Terdapat perbedaan Return On Asset antara perusahaan manufaktur yang besertifikat ISO 9001:2008 dan perusahaan yang tidak besertifikat ISO 9001:2008.

Pada table pengujian diatas dapat disimpulkan bahwa perbedaan kinerja antara perusahaan yang memiliki ISO dengan yang non ISO 9001memiliki perbedaan pada penggolongan kelompok hasil uji hipotesis terlihat kelompok ISO mendapat peringkat kelompok lebih tinggi dibandingkan kelompok NonISO tetapi perbedaan yang signifikan hanya terlihat pada rasio Return On Assetdan pada Nett Asset, Net profit Margin dan revenue tidak memiliki perbedaan yang signifikan. Hasil dari penelitian disimpulkan bahwa perusahaan manufaktur yang tidak menggunakan sertifikasi ISO sudah menjalankan managemen mutu dengan baik sehingga hasil penelitian ini tidak signifikan terhadap asset, net profit margin dan revenue. Hasil penelitian dapat disimpulkan bahwa perusahaan yang tidak menerapkan ISO dan yang menerapkan ISO memiliki total asset yang tidak jauh berbeda, dalam penelitian ini sampel yang digunakan ialah perusahaan go public yang memiliki sekala industri besar.

\subsection{Analisis Data}

Berdasarkan hasil uji statistik yang telah dilakukan hipotesis penelitian ini dinyatakan diterima.

4.4.1 Terdapat perbedaan Net Profit Margin antara perusahaan manufaktur yang besertifikat ISO 9001:2008 dan perusahaan yang tidak besertifikat ISO 9001:2008

Dari hasil uji statistik diatas, bahwa Hipotesis tidak diterima, pada hasil penelitian menunjukkan bahwa tidak terdapat perbedaan yang signifikan terhadap laba bersih perusahaan yang memiliki ISO 9001 dengan perusahaan non-ISO 9001. Pada penelitian ini dapat dilihat bahwa perusahaan yang sudah memiliki ISO 9001 menghasilkan profit yang tidak berbeda dari perusahaan yang tidak menggunakan ISO 9001, sehingga dapat dikatakan bahwa ISO 9001:2008 tidak memiliki pengaruh pada laba bersih perusahaan. Pada penelitian sebelumnya oleh Ochieng et al, (2015) juga menunjukkan hal yg sama, sertifikasi ISO 9001:2008 tidak signifikan terhadap Net Profit.

4.4.2 Terdapat perbedaan Revenue antara perusahaan manufaktur yang besertifikat ISO 9001:2008 dan perusahaan yang tidak besertifikat ISO 9001:2008

Dari hasil uji statistik diatas, bahwa Hipotesis tidak diterima pada hasil penelitiannya menunjukkan bahwa tidak terdapat perbedaan yang signifikan terhadap pendapatan perusahaan yang memiliki ISO 9001 dengan perusahaan non-ISO 9001. Pada penelitian sebelumnya oleh Ochieng et al,. (2015) juga menunjukkan hal yg sama sertifikasi ISO 9001:2008 tidak signifikan terhadap revenue. Pada penelitian ini dapat dilihat bahwa perusahaan yang sudah memiliki ISO 9001 menghasilkan pendapatan yang tidak berbeda dari perusahaan yang tidak menggunakan ISO 9001, sehingga dapat dikatakan bahwa ISO 9001:2008 tidak berpengaruh pada pendapatan perusahaan.

4.4.3 Terdapat perbedaan Net Asset antara perusahaan manufaktur yang besertifikat ISO 9001:2008 dan perusahaan yang tidak besertifikat ISO 9001:2008

Dari hasil uji statistik diatas, bahwa Hipotesis tidak diterima pada hasil penelitiannya menunjukkan bahwatidak terdapat perbedaan yang signifikan terhadap Net Asset perusahaan yang memiliki ISO 9001 dengan perusahaan non-ISO 9001. Pada penelitian sebelumnya oleh Ochieng et al,. (2015) juga menunjukkan hal yg sama sertifikasi ISO 9001:2008 tidak signifikan terhadap Net Asset. Pada 
penelitian ini dapat dilihat bahwa perusahaan yang sudah memiliki ISO 9001 dan yang tidak memiliki sertifikat 9001:2008 memiliki asset bersih yang tidak berbeda, jadi dapat dikatakan bahwa ISO 9001:2008 tidak berpengaruh pada asset bersih perusahaan.

4.4.4 Terdapat perbedaan Return On Assests antara perusahaan manufaktur yang besertifikat ISO 9001:2008 dan perusahaan yang tidak besertifikat ISO 9001:2008

Dari hasil uji statistik diatas, bahwa Hipotesis terdukung, oleh penelitian sebelumnya oleh Ochieng et al,. (2015) juga menunjukkan hal yg sama sertifikasi ISO 9001:2008 signifikan terhadap rasio ROA juga pada penelitian Mokhtar et al., (2012) yang menunjukkan adanya perbedaan rasio ROA pada perusahaan yang memiliki sertifikat 9001 dengan perusahan yang tidak memiliki sertifikat ISO 9001. Pada penelitian ini dapat dilihat bahwa perusahaan yang sudah memiliki ISO 9001 menghasilkan ROA yang berbeda dari perusahaan yang tidak menggunakan ISO 9001, sehingga dapat dikatakan bahwa ISO 9001:2008 berpengaruh pada rasio ROA perusahaan.

\subsection{Simpulan}

Berdasarkan hasil penelitian mengenai komparasi kinerja perusahaan yang memiliki ISO 9001 dengan perusahaan yang tidak memiliki sertifikat ISO 9001 dapat ditarik kesimpulan yang sesuai dengan perumusan masalah dan tujuan dari penelitian ini yaitu pada revenue, Net Profit Margin dan Net Asset perusahaan tidak signifikan atau dapat dikatakan tidak memiliki perbedaan antaraa perusahaan manufaktur yang memiliki ISO 9001:2008 dengan perusahaan manufaktur yang tidak memiliki ISO 9001:2008.

Pada penelitian ini dapat dilihat bahwa pengaplikasikan ISO 9001:2008 pada perusahaan akan berpengaruh pada tingkat pengembalian terhadap asset perusahaan akan semakin baik dibanding dengan perusahaan manufakturyang tidak memiliki setifikat ISO 9001:2008. Tetapi pada pengukuran lainnya seperti yang dipakai pada penelitian ini yaitu pendapatan, laba bersih dan asset bersih perusahaan tidak memiliki perbedaan yang signifikan terhadap kepemilikan ISO.

\subsection{Keterbatasan} berikut:

Penelitian ini memiliki keterbatasan sebagai

a. Penelitian hanya mengambil sampel 3 tahun laporan keuangaan perusahaan, dengan mengambil semakin banyak tahun laporan keuangan perusahaan dapat meningkatkan kualitas dari hasil penelitian.

b. Banyaknya perusahaan yang tidak memiliki data keuangan lengkap selama 3 tahun.

c. Penelitian ini hanya meneliti perusahaan manufaktur saja

\subsection{Implikasi dan Saran}

\subsubsection{Implikasi}

Melihat hasil dari peneitian ini perusahaan yang menggunakan ISO 9001 dan perusahaan non-ISO 9001 memiliki perbedaan pada rasio Return On Asset nya dan perusahaan yang mempunyai ISO 9001 dinyatakan memiliki tingkat pengembalian pada aset yang lebih baik, maka penelitian dapat dijadikan informasi dan bahan pertmbangan kepada perusahaan non-ISO untuk dapat mengaplikasikan ISO 9001 pada perusahaannya.

\subsubsection{Saran}

Dari keterbatasan penelitian yang diuraikan diatas, peneliti memberikan saran sebagai berikut:

a. Penelitian selanjutnya dapat meneliti sektor yang lainnya atau menambah sector lain,memungkinkan terjadi perbedaan hasil dari penelitian ini

b. Disarankan pada penelitian selanjutnya juga untuk meneliti laporan keuangan dengan periode lebih panjang guna hasil penelitian yang lebih baik.

c. Penelitian selanjutnya dapat menambahkan rasio keuangan lainnya sebagai alat ukur kinerja perusahaan guna hasil penelitian yang lebih baik.

\section{DAFTAR PUSTAKA}

Berita Industrial. (2016). Manufaktur Sumbang $40 \% \quad$ PDB. 26 Januari 2016 http://kemenperin.go.id/artikel/5787/Manu faktur-Sumbang-40-PDB.

Cendrawati , \& Haryanto , M. (2011). Analisis Pengaruh Sertifikasi ISO 9000 terhadap Rasio Return on Investmens Perusahaan Manufaktur yang terdaftar di Bursa Efek Indonesia. Jurnal Bisnis dan Akuntansi, 211-228. 
Chatzoglou, P., Chatzoudes, D., \& Kipraios, N. (2015). The impact of ISO 9000 certification on firms' financial performance. International Journal of Operations \& Production Management, 145-174.

Diensa, P. (2013). Pengaruh Kinerja Keuangan Perusahaan Terhadap Harga Saham (Studi Empiris pada Perusahaan Manufaktur yang Terdaftar di BEI Tahun 2010-2011). Pengaruh Kinerja Keuangan Perusahaan Terhadap Harga Saham.

Fahmi, I. (2011). Analsis Kinerja Keuangan. Bandung: Alfabeta.

Gasperz, \& Vincent. (2002). ISO 9001 : 2000 and Contunial Quality Improvement. jakarta: PT. Gramedia Pustaka Utama.

Hartono, j. (2014). teori portofolio dan analisis investasi. In j. hartono, teori portofolio dan analisis investasi. BPFE: Yogyakarta.

Hasen, Don R., \& Mowen, M. (2003). Managemen accounting. cincinnati: South Western College Publishing.

Harmono, 2014. Manajemen Keuangan, Berbasis Balanced Scorecard Pendekatan Teori, Kasus dan Riset Bisnis

Jogiyanto. 2007. Metodologi Penelitian Bisnis. Edisi 6

Mokhtar, et al. 2012. Comparative Study on Performance and Atributes between ISO and Non-Iso Certification Companies. International Journal of Business and Management.

Ochieng, J., Muturi, D., \& Njihia, S. N. (2015). The impact of ISO 9001 implementation on organizational performance in Kenya.

The TQM Journal, 761-771.

Prawironegoro, d., \& purwanti, a. (2008). Akuntansi manajemen. jakarta : Mitra Wacana Media.

Psomas, E., \& Dimitrios, K. (2014) Performancemeasures of ISO 9001 certified and non-certified manufacturing companies. Benchmarking: An International, 756-774.

Rusliati, E. (2010). Pemecahan Saham Terhadap Likuiditas dan Return Saham. E-Jurnal Akuntansi Universitas Udayana, Vol. 12, No. 3, Desember 2010, Hlm 161 - 174.

Sertification, Oss. (2016). PT Oss Sertifikasi internasional. Retrieved januari 26, 2016, from PT Oss Sertivication International web site: http://www.osscertification.co.id/

Sulaiman, W. (2003). Statistik Non-Parametrik contoh Kasus dan Pemecahannya dengan SPSS. Yogyakarta: Andi.

Summers, D. S. (2009). Quality Management: Creating and Sustaining Organizational Effectiveness. Upper Saddle River: Pearson Education Inc.

Susilawati, C., Salim, F., \& Soesilo, T. (2005). Harapan dan Realita Sistem Manajemen Mutu ISO 9000 dalam Penerapannya di Perusahaan Kntraktor. Civil Engineering Dimension, 30 - 35 .

Sutapa, N. ( 2012). Peranan Manajemen Puncak, Wakil Manajemen, dan Konsultan dalam Tahap Awal Penerapan Sistem Manajemen Mutu. Jurnal Teknik Industri. 